\title{
Modifikikasi Sistem Cairan Intravena Menurunkan Infeksi Nosokomial di NICU-Harapan Kita
}

\author{
Setyadewi Lusyati*, Ferdy P.Harahap*, Hulzebos $C^{* *}$, Bos AF ${ }^{* *}$, Sauer PJ \\ * Unit Kerja Neonatologi-Bagian Ilmu Kesehatan Anak RSAB Harapan Kita, Jakarta \\ ** Neonatology Subdivision-Pediatric Department, University Medical Centre Groningen, \\ Netherlands
}

\begin{abstract}
Latar belakang. Infeksi adalah salah satu penyebab utama morbiditas dan mortalitas di NICU. Sumber infeksi tidak selalu jelas, cairan intravena mungkin merupakan salah satu penyebab.

Tujuan Penelitian. Mengevaluasi pengaruh cairan intravena, baik cara pemberian maupun frekuensi penggantian cairan terhadap kejadian infeksi di NICU RSAB Harapan Kita.

Metode. Studi uji silang dilakukan di NICU terhadap 2 kelompok bayi pada periode waktu yang berbeda. Kelompok I (periode Juni-Juli,2006) adalah kelompok 'infus semi terbuka' menggunakan buret, diganti tiap 2-7 hari. Kelompok II (periode September-Oktober,2006) adalah kelompok 'infus tertutup' menggunakan semprit, diganti tiap 8 jam. Angka kejadian infeksi dihitung berdasarkan adanya bakteri di dalam biakan darah pada periode tersebut.

Hasil. Didapatkan 68 bayi dari kelompok I (berat lahir rerata $2364 \pm 840$ gram, usia gestasi rerata 35.5 \pm 3.9 minggu) dan 54 bayi di kelompok II (BBL rerata $2479 \pm 884$ gram, usia gestasi $36.2 \pm 2.6 \mathrm{minggu}$ ) Insidensi infeksi nosokomial lebih rendah daripada kelompok II dibandingkan kelompok I (35/68 dan 5/ 54, OR=0.1; 95\% interval kepercayaan: 0.034-0.271; p<0.001). Pada kelompok I, 31/56 bayi didapatkan biakan darah II menjadi positif, sedangkan pada kelompok II hanya terdapat 3/48 bayi dengan biakan darah II menjadi positif ( $<<0.001)$. Hasil biakan kelompok I, 30/35 adalah Serratia, sedangkan pada kelompok II didapatkan 5 spesimen ditemukan Serratia.

Kesimpulan. Pemberian cairan intravena sistem terbuka merupakan salah satu faktor utama penyebab tingginya infeksi nosokomial di RSAB Harapan Kita. Dengan memodifikasi cara pemberian dan frekuensi penggantian cairan intravena, kejadian infeksi nosokomial dapat diturunkan (Sari Pediatri 2007; 9(10):54-58).
\end{abstract}

Kata kunci: cairan intravena,infeksi nosokomial

\section{Alamat korespondensi:}

Dr. Setyadewi Lusyati Sp.A, Unit Kerja Neonatologi - Bag.Ilmu Kesehatan Anak RSAB Harapan Kita, Jakarta. Tel/fax: 62-21-53152570, E-mail: setyadewi13@yahoo.com.

Telah dipresentasikan pada Kongres 'Society for Pediatric Research', di Toronto, Canada, Mei, 2007.
I nfeksi meningkatkan morbiditas dan mortalitas neonatus, terutama pada bayi yang mendapat perawatan di 'Neonatal Intensive Care Unit' (NICU). Berdasarkan data yang dikumpulkan secara restrospektif selama 2 tahun di RSAB Harapan Kita, Jakarta, terdapat peningkatan angka kejadian 
infeksi dari $9 \%$ pada hari I menjadi $63 \%$ pada perawatan hari ke 3-5 di NICU. Didapatkan pula 56 kematian karena sepsis nosokomial terhadap 6600 total kelahiran pada periode tersebut (9,8 per 1000 kelahiran hidup) ${ }^{1}$ Angka tersebut kurang lebih sesuai dengan angka kematian karena sepsis nosokomial menurut IDAI (2001) yaitu 6,8 dari 1000 kelahiran hidup. Sumber potensial bakteri perlu dikenali untuk dapat membuat strategi penurunan kejadian infeksi nosokomial lebih terarah.

Cairan intravena terkontaminasi adalah problem utama di negara berkembang disebabkan karena belum dapat diadakan cairan standar di rumah sakit dan perawat membuat cairan intravena dalam kondisi kontrol infeksi yang rendah. Beberapa penelitian terdahulu melaporkan adanya kombinasi 3 bakteri yang dapat mencemari cairan intravena, yaitu: Klebsiella, Enterobacter $s p$ dan Serratia $s p .^{2,3}$ Pada era tahun 1980, dilaporkan epidemi sepsis dari cairan intravena yang terkontaminasi. ${ }^{4,5}$ Penelitian secara prospektif di Amerika Serikat membuktikan kejadian infeksi nosokomial dapat diturunkan dengan upaya mengurangi cairan intravena yang terkontaminasi. ${ }^{3,5}$

Dari observasi harian di NICU Harapan Kita, terdapat kesan bahwa bayi yang mendapat cairan intravena baik melalui vena sentral atau perifer sering mengalami infeksi nosokomial dibanding bayi yang tidak mendapat cairan intravena meski mempunyai akses intra vena untuk memasukkan obat. Sehingga muncul dugaan bahwa cairan intravena yang diberikan pada bayi yang dirawat di NICU mengalami kontaminasi dan berperan utama meningkatkan angka kejadian infeksi. Tujuan dari penelitian ini untuk membandingkan angka kejadian infeksi pada dua periode cara pemberian cairan intravena yang berbeda.

\section{Metode}

Uji silang observasional dilakukan pada dua kelompok bayi di NICU RSAB Harapan Kita-Jakarta yang dirawat pada periode yang berbeda. Semua bayi yang dirawat pada dua periode tersebut diikutsertakan dalam penelitian. Periode I adalah periode pemberian cairan intravena dengan menggunakan prosedur yang biasa dilakukan sebelumnya. Prosedur yang biasa dipakai adalah, pembuatan cairan intravena berdasarkan instruksi dokter kepada perawat untuk membuat cairan intravena di ruang NICU dengan metode aseptis. Cairan hari pertama adalah dextrosa 5\% atau10\% disertai kalsium glukonas $10 \%$, selanjutnya pada hari ke 2 atau 3 cairan ditambahkan dengan elektrolit. Cairan diberikan dengan menggunakan kantong infus dextrosa dan dihubungkan dengan buret (yang mempunyai 'injection port') secara kontinyu. Prosedur pemberian cairan intravena dikatakan semi terbuka karena perubahan baik konsentrasi, jenis ataupun penambahan elektrolit diberikan dengan cara menyuntikkan cairan elektrolit melalui 'injection port.' Cairan diberikan kepada pasien dengan menggunakan pompa infus; Pemberian cairan nutrisi parenteral (asam amino dan atau intralipid) diberikan dengan cara menggunakan semprit $50 \mathrm{ml}$ secara terpisah dengan menggunakan pompa semprit. Buret dan set infus diganti 3-7 hari tergantung dari kebutuhan cairan sehari. Penggantian asam amino dan intralipid disesuaikan juga dengan kebutuhan, lama pemakaian sekitar 24-48 jam.

Sejak bulan Agustus 2006 mulai disosialisasikan prosedur pemberian intravena baru. Prosedur tersebut adalah: cairan diberikan dengan menggunakan semprit $50 \mathrm{ml}$ dan dihubungkan ke set infus. Pemberian dengan menggunakan pompa semprit. Pemberian cairan nutrisi parenteral (asam amino dan atau intralipid) diberikan dengan cara menggunakan semprit $50 \mathrm{ml}$ secara terpisah dengan menggunakan pompa semprit. Penggantian cairan intravena dan semprit dilakukan tiap 8 jam sehingga penyesuaian oleh karena perubahan jenis cairan atau koreksi elektrolit dilakukan pada saat penggantian semprit. Set infus diganti tiap 3 hari. Penggantian cairan asam amino atau intralipid serta sempritnya dibatasi tidak lebih dari 24 jam. Asam amino dan intralipid juga diberikan secara terpisah.

Pengambilan data dilakukan secara restrospektif dari catatan medis. Semua bayi yang dirawat pada dua periode tersebut diikutsertakan penelitian, kecuali bayi dengan kelainan bawaan yang fatal (seperti trisomi 13, trisomi 18, bayi dengan sindrom hipoplasi jantung kiri)

Kelompok I adalah kelompok periode I, seluruh bayi yang dirawat di NICU pada bulan Juni-Juli 2006 yang mendapat cairan intravena prosedur lama.

Kelompok II adalah kelompok periode II, seluruh bayi yang dirawat di NICU pada bulan SeptemberOktober 2006 yang mendapat cairan intravena prosedur modifikasi. Namun sebagian kecil bayi pada periode tersebut masih mendapat cairan intravena dengan prosedur lama bila kebutuhan cairan lebih dari $50 \mathrm{cc} / 8$ jam. 
Pencatatan data bayi meliputi berat badan lahir, usia kehamilan, jenis kelamin, lama rawat, outcome dan pola bakteri dari dua biakan darah. Semua bayi mendapat skrining rutin untuk infeksi pada perawatan hari ke 1 (darah tepi, CRP dan biakan darah), biakan darah diulang pada perawatan hari ke 3-5 bila bayi tidak membaik secara klinis. Diagnosis infeksi ditegakkan bila didapatkan bakteri patogen di dalam biakan.

Uji statistik dilakukan untuk mengevaluasi perbedaan kejadian infeksi antara 2 kelompok/periode infus. Analisis statistik menggunakan uji x2. Tabulasi data dan uji statistik dengan menggunakan perangkat lunak SPSS 10.0.

\section{Hasil}

Didapatkan 75 bayi kelompok I, pada periode I, dengan cairan intravena prosedur lama (kelompok I, infus semi terbuka) dan 56 bayi pada kelompok II, periode II, cairan intravena modifikasi (kelompok II, infus tertutup). Bayi tidak diikutsertakan dalam penelitian karena tidak ditemukan catatan medisnya atau mempunyai kelainan bawaan yang fatal. Terdapat 68 dari 75 bayi pada kelompok I dan 54 dari 56 bayi pada kelompok II yang dapat dianalisis. Karakteristik bayi antara dua kelompok seperti terdapat pada Tabel 1 .

Pada kelompok II didapatkan proporsi biakan darah positif lebih rendah terhadap kelompok I (35/ 68 vs. $5 / 54, \mathrm{OR}=0.1 ; 95 \%$ CI: $0.034-0.271 ; p<0.001$ ). Dari kelompok I, 31 dari 56 bayi dengan biakan darah hari ke 1 negatif menjadi positif pada biakan hari ke 3-5, sedangkan pada kelompok II hanya 3 dari 48 bayi menjadi positif pada biakan darah II $(p<0.001)$.

Pada kelompok I, didapatkan 6 spesimen positif terhadap Serratia sp pada biakan darah hari ke I menjadi 30 dari 36 biakan darah hari ke 3-5 yang diperiksa, sedangkan pada kelompok II 3 spesimen positif Serratia sp pada kelompok I menjadi 5 dari 8 biakan darah yang diperiksa. Tidak didapatkan kuman lain pada kelompok II. Sedangkan pada kelompok I terdapat peningkatan jumlah bakteri Enterobacter aerogenes (1 menjadi 3 jenis bakteri).

\section{Diskusi}

Penelitian sebelumnya mengemukakan bahwa kontaminasi bakteri tidak ditentukan oleh sarana yang digunakan. Didapatkan insidensi sama rendah antara dua kelompok cairan intravena mempergunakan buret dan semprit dengan sistem penggantian 24 jam. $^{6}$ Demikian juga dengan lama pemakaian set infus. Penggantian kantong infus dengan buret setelah pemakaian 48-72 jam dinilai aman dan tidak memicu kontaminasi bakteri, ${ }^{3,7}$ bahkan tidak didapatkan perbedaan dalam hal kolonisasi kuman antara penggantian set infus tiap 24 jam dibandingkan 2-7 hari dengan memakai kateter vena sentral. ${ }^{8}$ Namun Raad $\mathrm{dkk}^{9}$ (2001) menemukan peningkatan kolonisasi bakteri pada kelompok bayi dengan penggantian set infus lebih dari 3 hari bila mendapat TPN dengan atau transfusi darah. Penelitian yang dilakukan di negara berkembang oleh Macias ${ }^{10}$ (2005) menunjukkan adanya kontaminasi bakteri terutama bakteri gram negatif pada cairan intravena. Kontaminasi cairan intravena tampak meningkat bila set infus diganti lebih dari 24 jam.

Dari observasi yang dilakukan di RSAB Harapan Kita terhadap bayi yang dirawat di NICU, terdapat kecenderungan infeksi nosokomial yang tinggi (53\%) dalam periode dua bulan dengan infus semi terbuka (melalui buret dan koreksi cairan/elektrolit diberikan melalui injection port). Pada Tabel 2 terlihat penurunan kejadian infeksi yang sangat bermakna pada kelompok infus tertutup. Secara kasar angka infeksi nosokomial berkisar 8,9\% (1/6 kali kelompok I) pada periode dua

Tabel 1. Karakteristik bayi baru lahir

\begin{tabular}{llll}
\hline \multicolumn{1}{c}{ Variabel } & & Kelompok I (n=68) & Kelompok II (n=54) \\
\hline Usia gestasi (minggu) & Median & $37,0(26-41)$ & $37,0(27-42)$ \\
BBL (gram) & Median & $2325,0(900-4000)$ & $2400(930-5265)$ \\
Lama perawatan (hari) & Mean & $8.1(1-92)$ & $10,91(1-92)$ \\
Jenis kelamin (\%) & Laki laki & $28(58,8)$ & $35(64,8)$ \\
& Perempuan & $40(41,2)$ & $19(35,2)$ \\
Outcome (\%) & Meninggal & $15(27,9)$ & $10(17,9)$ \\
& Sembuh & $49(72,1)$ & $46(82,1)$ \\
\hline
\end{tabular}


bulan tersebut. Pada kasus tidak didapatkan bakteri pada kultur darah II sesuai dengan membaiknya keadaan infeksi bayi secara klinis.

Pada penelitian ini didapatkan bakteri gram negatif adalah bakteri penyebab utama dan Serratia sp adalah bakteri gram negatif dominan pada ke dua onset sepsis pada kedua kelompok infus (Tabel 3). Hal tersebut sesuai dengan pola bakteri yang didapat pada penelitian sebelumnya di NICU RSAB Harapan Kita. ${ }^{1}$ Namun pada kelompok II/infus tertutup, angka kejadian sepsis karena Serratia sp. menurun tajam (Tabel 3). Penemuan ini memperkuat dugaan bahwa sistem infus semi terbuka berisiko tinggi pencemaran bakteri gram negatif terutama Serratia $s p$ dan merupakan sumber potensial bakteri untuk kejadian sepsis nosokomial di NICU RSAB Harapan Kita. Menyusul ditemukannya bakteri lain yaitu E. Aerogenes pada kelompok semi terbuka, sesuai dengan studi yang mengemukakan bahwa 'Tribe Klebsiella' (Klebsiella, E.aerogenes dan Serratia) adalah tiga bakteri dominan dapat bermultiplikasi di cairan infus. ${ }^{3,11,12}$ Meskipun modifikasi cairan intravena tampak dapat menurunkan kejadian infeksi secara bermakna, perlu dibuktikan keberadaan bakteri di cairan intravena.
Meskipun angka Serratia tampak menurun tajam pada kelompok infus tertutup, bila diteliti dari Tabel 2 dan 3, ditemukan penambahan jumlah bakteri Serratia pada kelompok II/infus tertutup (3 dalam biakan darah I menjadi 5 Serratia di biakan darah II). Hal ini menunjukkan terdapat sumber potensial bakteri lain yang perlu dicari.

Dari Tabel 1 tampak tidak ada perbedaan antara 2 kelompok dalam lama perawatan dan mortalitas. Hal ini sesuai dengan penelitian sebelumnya bahwa penurunan kontaminasi cairan intravena tidak berhubungan langsung dengan penurunan mortalitas neonatus. ${ }^{13}$ Namun hal ini memerlukan pengkajian lebih lanjut dan data yang lebih rinci untuk dapat membuat kesimpulan.

\section{Kesimpulan}

Pemberian cairan intravena semi terbuka ikut berperan terhadap kejadian infeksi nosokomial di NICU RSAB Harapan Kita. Modifikasi pemberian cairan intravena (melalui semprit dan diganti kurang dari 24 jam) dapat menurunkan kejadian bakteriemia. Didapatkan

Tabel 2. Angka kejadian bakteriemia antara 2 kelompok berdasarkan biakan darah hari ke 1 dan hari ke 3-5

\begin{tabular}{ccccccc}
\hline Kultur darah & \multicolumn{3}{c}{$\begin{array}{c}\text { Kultur darah hari ke 3-5 } \\
\text { kelompok I }\end{array}$} & \multicolumn{3}{c}{$\begin{array}{c}\text { Kultur darah hari ke 3-5 } \\
\text { kelompok II }\end{array}$} \\
\cline { 2 - 7 } & negatif & positif & total & negatif & positif & total \\
\hline Negatif & 25 & 31 & 56 & 45 & 3 & 48 \\
Positif & 8 & 4 & 12 & 4 & 2 & 6 \\
\hline Total & 33 & 35 & 68 & 49 & 5 & 54 \\
\hline
\end{tabular}

Tabel 3. Perubahan patogen pada kultur darah hari ke 1 dan hari ke 3-5 antara 2 kelompok infus Presentase patogen kultur darah

\begin{tabular}{|c|c|c|c|c|}
\hline \multirow{3}{*}{ Patogen } & \multirow{2}{*}{\multicolumn{2}{|c|}{ Kelompok I (n=68) }} & \multirow{2}{*}{\multicolumn{2}{|c|}{ Kelompok II $(\mathrm{n}=56$}} \\
\hline & & & & \\
\hline & $\mathrm{H} 1$ & $\mathrm{H} 3-5$ & $\mathrm{H} 1$ & $\mathrm{H} 3-5$ \\
\hline Serratia sp & $6(8,8)$ & $30(44,1)$ & $3(5,4)$ & $5(8,9)$ \\
\hline Klebsiella sp & $2(2,9)$ & $0(0)$ & \multicolumn{2}{|c|}{-} \\
\hline Candida sp & $2(2,9)$ & $0(0)$ & $1(1,8)$ & $0(0)$ \\
\hline E. aerogenes & $1(1,5)$ & $3(4,4)$ & \multicolumn{2}{|c|}{-} \\
\hline S. epidermidis & $1(1,5)$ & $1(1,5)$ & \multicolumn{2}{|c|}{-} \\
\hline E.coli & $0(0)$ & $1(1,5)$ & $2(3,6)$ & $0(0)$ \\
\hline X. malthofilia & $0(0)$ & $1(1,5)$ & $1(1,8)$ & $0(0)$ \\
\hline P. aeruginosa & \multicolumn{2}{|c|}{ _- } & $1(1,8)$ & $0(0)$ \\
\hline
\end{tabular}


penurunan bakteri Serratia dan E. aerogenes setelah modifikasi infus. Sistem pemberian intravena tertutup adalah standar minimal dalam proses pembuatan dan pemberian infus.

\section{Ucapan terima kasih}

Kami ucapkan terima kasih pada Bpk. Hadyana Sukandar atas bantuannya dalam analisa statistik.

Penulis mendapat dukungan dana dari Nestle Nutrition Institute-Pediatric Program Scholarship Award 2005 Switzerland, dalam bidang Neonatologi Studies, yang diberikan pada Kongres Pediatric Gastroenterology and Nutrition di Porto, Portugal, Juni, 2005.

\section{Daftar Pustaka}

1. S Lusyati, W. Marnoto, Paul vd Broek, PJ Sauer. Neonatal sepsis in a Neonatal Intensive Care Unit in Indonesia, 2005. (in press)

2. Macias AE, Munos JM, Bruckner DA. Parenteral Infusion Bacterial Contamination in a Multi Institutional Survey in Mexico: Consideration for Nosocomial Mortality. Am J Infect Control, 1999; 27:285-90

3. Maki DG, Botticelli JT, LeRoy ML, Thielke TS. Prospective study of replacing administration sets for intravenous therapy at 48 vs 72 hours intervals. 72 hours is safe and cost-effective. JAMA,1987; 258: 1777-81

4. Hernandes-Ramos, Gaitan M, Leon Ramirez AR, Justiniani CN, Avila FC. Extrinsic contamination of intravenous infusates administered to hospitalized children in Mexico. Pediatr Infect Dis J, 2000; 19:888-90

5. Maki DG. Infection due to infusion therapy. In: Bennet JV, Brachman PS, Sanford JP, penyunting
Hospital Infections. Boston:Little, Brown and Company; 1992:849-92

6. Reiter PD, Robies J, Dowell EB. Effect of 24 hour intravenous tubing set change on the sterility of repackaged fat emulsion in neonates. Ann Pharmacother, 2004; 38:1603-7

7. Gorbea HF. Snydman DR, Delaney A, Stockman J, Martin WJ. Intravenous tubing with burettes can be safely changed at 48 hour intervals. JAMA, 1984; 251:112-5

8. Richards CM, Lipman J, Courtney M, Siversen R, Daley P. Routine changing of intravenous administration sets does not reduce colonization or infection in central venous catheters. Infect Control Hosp Epidemiol, 2004;25:650-5

9. Raad I, Hanna HA, Awad A, Alrahwan A, Bivins C, Khan A. Optimal frequency of changing intravenous administration sets: is it safe to prolong use beyond 72 hours?. Infect Hosp Control Epidemiol, 2001; 22:1369

10. Macias AE, Munoz JM, Galvan A, Gonzales JA, Medina $\mathrm{H}$, Alpuche $\mathrm{C}$ et al. Nosocomial bacteriemia in neonates related to poor standards of care. The Pediatr Infectious Disease Journal, 2005;24:713-16

11. Elaine LL, Jeannie PC, Cimiotti RN, Janet H, Mirjana N, Ari A. Gram negative bacilli associated with catheter associated and non catheter associated bloodstream infections and hand carriage by healthcare workers in neonatal intensive care units. Pediatr Crit Care Med, 2005;6:457-61

12. Maki DG, Martin WT. Nationwide epidemic of septicaemia caused by contaminated infusion products: IV. Growth of microbial pathogen in fluids for intravenous infusion. J Infect Dis, 1975;131:267-72

13. Josephson A, Gombert ME, Sierra MF, Karanfil LV, Tansino GF. The relationship between intravenous fluid contamination and the frequency of tubing replacement. Infect Control,1985; 6:367-70 